\title{
Assessment of Accounting Competencies Possessed by Postgraduate University Business Education Students to Handle Entrepreneurship Business Challenges in Nigeria
}

\author{
James Okoro ${ }^{1, *}$ \\ ${ }^{1}$ Institute of Education, Delta State University, Abraka, Nigeria \\ *Correspondence: Institute of Education, Delta State University, Abraka, Nigeria. Tel: 234-803-537-8591 \\ E-mail: jimkorokpeu@yahoo.com
}

Received: September 27, 2013

Accepted: December 11, 2013

Online Published: December 27, 2013

doi:10.5430/wje.v4n1p1

URL: http://dx.doi.org/10.5430/wje.v4n1p1

\begin{abstract}
University Business Education graduates, by the nature of their programme, ought to possess relevant accounting competencies for successful entrepreneurship but casual observation and empirical reports indicate that they are not doing well in this aspect. Therefore, this study assessed the accounting competencies possessed by university postgraduate Business Education students to handle entrepreneurship business challenges in Nigeria. One research question and five hypotheses guided the study. Descriptive survey design was adopted for the study. The population, also used as the sample, consisted of 388 Business Education graduates who are currently running their postgraduate programme in universities in the south-east and south-south geopolitical zones in Nigeria. The questionnaire was adequately validated by experts in Business Education and measurement and evaluation. The internal consistency of the instrument was determined using Cronbach alpha which has a reliability coefficient of 0.94 . The mean and standard deviation were used to answer the research questions while Z-test was used to test the hypotheses at 0.05 level of significance. The result revealed that Business Education graduates are competent in ability to plan for small or medium scale businesses, ability to source funds for the running of a small scale business among others. However, they are not competent in preparation of tax codes and setting up of a currency. It was recommended that Business Education graduates should undergo training in conferences and workshops to enable them possess more effective accounting knowledge.
\end{abstract}

Keywords: assessment; accounting competencies; possessed; university business education graduates; handle business challenges; Nigeria

\section{Introduction}

Education has a significant role in the development of any nation. The National Policy on Education (NPE) defines education as an instrument for national development (Federal Republic of Nigeria, 2009). The N.P.E. also states that education enables a society to foster the value, behaviour and lifestyle appropriate for a sustainable development of any nation. Education can be seen as a process of learning that has future benefits in building the capacity of the citizens for a meaningful engagement of the forces that shape socio-economic development (Abdulkadir, 2011). Therefore, education is a medium through which the society transmits skills, attitudes and behaviours to its younger ones, in order to provide a better life for the society and its members. Business education is categorized among vocational education in tertiary institution. Business education is an education for vocation. Osuala (2004) opines that it is a training system that encourages the beneficiary to acquire skills that will make him/her fit into the world of work. Business Education is an educational programme that prepares the individual for the world of work as a teacher, office employee or to be self-employed.

Business Education is an education for and about business or training in business courses necessary to set-up private businesses (Esene, 2012). The objectives of Business Education according to Okoro (2008) are:

- To produce competent graduates to teach Business Education subjects in secondary schools. 
- To produce competent graduates for self-employment and self-reliance

- To produce competent graduates for office occupation

- To produce competent graduates for the industries

- To produce competent graduates for the public sector

Business Education is taught both at the College of Education and at the university. Courses in accounting, management, marketing, office technology and management are taught. Business Education serves as a very significant means through which a nation can achieve its ultimate goals in business especially if it is supported with entrepreneurship education and is properly nurtured and articulated to provide initiatives, self-employment, management and marketing skills, and is geared towards risk-taking and problem solving (Hynes 1996). It stretches the acquisition of knowledge relevant to employment and demonstrable job specific skills or competences. Competencies are abilities of power and authority of knowledge, attitudes and facts necessary for accomplishing tasks (Achilike \& Okwuanaso, 2001). Competencies, therefore, are the knowledge, skills and behaviours that enable an employee to meet established performance criteria. Ente, Amusa and Eze (2009) view competencies as essential knowledge and skills obtainable in a profession and those which the professionals in the field must possess and be able to demonstrate at optimal level of acquisition and functioning. Quality service or job can only be rendered when one has the knowledge, competencies and attitude required in the profession.

Business Education prepares its graduates for employment in the work-place, typical existing business enterprises as well as the acquisition of knowledge relevant to employment. The Business Education programme basically equips the individual with skills and abilities. The relevance of the programme has to do with its practical acquisition and application of basic skills for real life situations. An important characteristic of the Business Education programme is that its products can function independently as self-employed and employers of labour. It is unfortunate that products of Business Education end up rubbing shoulders with products of other programmes (Abdulkadir, 2011). It has the consequence of decreasing employment in both government and private organizations. The products of Business Education seem to lack the necessary entrepreneurship skills, most especially accounting skills, to set up and maintain their own businesses.

There is hardly any sphere of life where the knowledge of accounting is not required. Indeed, it may not be an exaggeration to say that everyone practices accounting. The implication of the above assertion is that we all use accounting techniques (budgeting, recording of financial transactions and so on) and accounting information in our daily lives. However, it is in the realm of business that accounting appears to be most popular. Frank (2000) opines that recording is the language of business as it is used in the business world to describe the transaction and communicate to interested parties after analysis and interpretation from transaction entered into by all kinds of organisations. Adeosun (2004) states that:

Users of accounting information such as shareholders, employees, labour leaders, internal revenue services, researchers, creditors, auditors and so on, make use of financial statements prepared by company directors. Individuals must plan to use their resources (which are scarce) to meet their endless list of wants. This would call for budgeting and planning. Government at different levels local, state and federal (especially in a democracy) would have to report on their stewardship to the electorates. This would warrant preparation of financial statements showing if revenue received has been utilized properly.

It has been explained in the preceding paragraph that knowledge and use of accounting are pervasive. Nevertheless, when financial statements are to be presented to a highly varied audience in annual general meetings of public listed shares for subscription in companies, it is expected that accounting information to be presented must meet certain legal standards and conform generally to prescribed principles.

Adetifa, Ajileye and Oluwasanmi (2001) define accounting as the art of recording, classifying and summarizing in a useful manner and in monetary terms, transactions and events which are of financial character and the subsequent interpretation. Also Osuwa (2002) observes that accounting is the process by which data relating to economic activities of an organization are measured and recorded. Okoli (2013) defines accounting as the process of recording, classifying, selecting, measuring, interpreting, summarizing and reporting financial data of an organization to the users for objective assessment and decision making. Accounting is a service activity and its function is to provide quantitative information, primarily financial in nature, about economic entities that is intended to be useful in making economic decisions. It provides quantitative financial information about economic entities to statement users so that they could make informed judgement and better decision (Okoli, 2013). In the same vein, Azih (2013) defines accounting as the 
process of recording, classifying, summarizing, analysing and interpreting financial transactions and communicating the results thereof to interested users. Accounting education equips the recipients with saleable skills that prepare them for dual jobs. Graduates of the programme can either teach accounting subjects or serve as accounting officers in various public and private parastatals. Azih (2013) further states that the technological change in the storage and retrieval of accounting information in organizations has affected the demands from accounting education graduates which involves adequate knowledge of the skills in storage and provision of information to the interested users in a paperless office. Ugeh (2013) notes that accounting is an art of recording, classifying and summarising monetary transactions or events which are of financial character and interpretation of the results. The different economic systems have the tremendous influence on the accounting process. The evolution of accounting, therefore, is a product of its socio-economic environment. From these definitions, it can be seen that accounting deals with the use of data or facts to produce information necessary for decision making by different users of such information such as mangers, employers and so on. On the other hand, accounting education has been described by Ehiametalor (1990) as a programme of instruction which aims at inculcating in the students the following abilities:

- Management of personal finances

- Making relational economic choices

- Investing wisely both in consumable items and non-immediate consumable item; and

- Reconciling one's assets and liabilities.

Ehiametalor's proposition on the use of accounting education tends to reiterate the vocational use of accounting preparation of graduates for a job employment within a wide range of business career and more especially the management of personal finances and resources. Osuwa (2002) remarks that accounting education is fundamentally a programme that has to do with acquisition, conversion and how to record business transactions. Osuwa also asserts further, that it is a type of education for self-reliance”. Thus the basic knowledge of accounting education will help the students to develop manipulative skills. It will also help to inculcate and develop in the students the attitude of using the acquired skills to solve problems in business and community.

The term competence refers to the minimum skills required of individuals who have participated in a course of programme. The graduate of Business Education (accounting) programme is expected to be knowledgeable in the three domains of learning as explained by Ehiametalor (1990) namely;

- Cognitive: Theories, sort out information, interpretation of data, motivation

- Psychomotor: Applications in the utilization of machines, arrangement of data to a format

- Affective: Communication effect, appreciation of the effort of other people's work performance, Appreciation of one's effort in group goal achievement

In the cognitive domain, accounting education graduates who would be required to act as executive officer (accounts) in the civil services and private companies or as teachers at the junior secondary school level must have a good grasp of the theoretical foundation of the subject matter of accounting, theories of evolution of book keeping and accounting, accounting standards, principles of finance and quantitativeness of the subject matter of accounts, theories of evolution of book keeping and accounting, accounting standards, principles of finance and quantitative techniques.

Furthermore, there is, the 'mental' cognitive exercise of sorting out information into meaningful things which is a necessary competence required for sorting transactions into different classes of accounts such as personal, impersonal, real, nominal and expenses. It is in the cognitive domain that competencies such as interpretation of data with the use of equations, ratios, percentages and so on are required. In the psychomotor domain, accounting education graduates must develop the competence of using their hands and brain to perform in the teaching and clerical functions. Competencies such as ability to manipulate calculators, franking machines, computers, etc. are required.

Okpan (2006) identifies some accounting skills required by Business Education graduates such as ability to keep accurate financial records, ability to understand ways of recording business transactions, ability to be acquainted with new trends as regards accounting role in the business world, ability to handle the various books of accounts and ability to interpret financial reports. In the same vein, Ekwue and Udoye (2008) identify the following accounting skills relevant to Business Education graduates:

- $\quad$ Ability to keep and control stocks

- $\quad$ Ability to avoid unplanned expenditure

- $\quad$ Ability to determine profit of a particular period 
- $\quad$ Ability to find out sources of capital to start business

- $\quad$ Ability to improve as well as develop basic skills in arithmetic

- $\quad$ Ability to understand ways of recording business transactions

- $\quad$ Ability to keep accurate financial records

- $\quad$ Ability to be acquainted with new trends as regards accounting role in the business world.

- $\quad$ Ability to determine where and when to invest

- $\quad$ Ability to be acquainted with new trends in relation to accounting concepts and convention

- $\quad$ Ability to undertake simple audit

- $\quad$ Ability to detect fraud

- $\quad$ Ability to handle various books of accounts

- $\quad$ Knowledge of Federal Government Tax Laws

- $\quad$ Ability to use bonus to increase productivity

- $\quad$ Ability to prepare sales, cash and production budget

- $\quad$ Ability to interpret simple financial statements

- $\quad$ Knowledge of simple business law

- $\quad$ Awareness of existence and use of professionals like bankers, accountants, lawyers, insurance agents and advertising agents

- $\quad$ Ability to keep and control inventory.

In the same vein, Azih (2010) identifies the following accounting competencies expected of Business Education graduates. These are preparation of tax codes, selecting settings of a department, setting up of a currency, designing of nominal records, preparation of control accounts, creating, amending and deleting nominal records, creating of bank, cash and credit accounts, preparation of profit and loss account, structure for coding customer and supply records, handling of opening balances, preparation of check data, backups, compress data files, rebuild data files, month end financial reports and budget report, correction of errors made while posting transactions and preparation of a bank reconciliation statement.

The above competencies will enable university Business Education graduates to function effectively in the world of work as successful entrepreneurs.

\section{Statement of the Problem}

University Business Education graduates by their education and training ought to possess the relevant competencies in accounting; competencies that will enable them establish and run their own businesses successfully. For a Business Education graduate to secure, maintain and sustain a job, the graduate needs more than manipulative skills. Furthermore, Okwuanaso (2004) indicates that the expectations for which the National Policy on Education introduced business Education in the Nigerian school system have not been fully met. Unfortunately, Akume's (2006) research findings revealed that many Business Education graduates that set their businesses come out with high rate of failure. He further states that, within a year, only about $50 \%$ of such businesses survive; in two years, about $18 \%$ of them survive while in three years, many of the businesses have liquidated. This uncertainty of success among Business Education graduates in running their businesses is a major concern to prospective entrepreneurs. There are doubts about the accounting competencies possessed by Business Education graduates. The problem of the study therefore, is to what extent do Business Education graduates possess relevant competencies in accounting?

\section{Purpose of the Study}

The purpose of this study was to assess accounting competencies possessed by university postgraduate Business Education students to handle entrepreneurship business challenges in Nigeria. Specifically, the study sought to assess entrepreneurial competencies possessed by university Business Education graduates in accounting. 


\section{Research Question}

The following research question was raised to guide the study:

To what extent do Business Education graduates possess relevant competencies in accounting?

\section{Hypotheses}

The following hypotheses were tested at 0.05 level of significance.

1. There is no significant difference between male and female university Business Education graduates in the mean ratings of their possessed competencies in accounting.

2. There is no significant difference between south east and south west universities Business Education graduates in the mean ratings of their possessed competencies in accounting.

3. There is no significant difference between B.Sc. and M.Ed university Business Education graduates in the mean ratings of their possessed competencies in accounting.

4. There is no significant difference between federal and state universities Business Education graduates in the mean ratings of their possessed competencies in accounting.

5. There is no significant difference between full-time and part-time university Business Education graduates in the mean ratings of their possessed competencies in accounting.

\section{Method}

This study adopted a descriptive survey design. A descriptive survey design was used for this study because it was aimed at ascertaining and establishing the status quo, facts of information concerning the population. According to Nworgu (1991), survey method is appropriate, especially for seeking individual's opinions, attitudes and perceptions in their natural setting. The population of the study comprised all university Business Education graduates who are currently undergoing their post-graduate programme in five universities in the area of study, namely, university of Benin, Benin City; University of Uyo, Uyo; Nnamdi Azikiwe University, Awka; University of Nigeria, Nsukka and Ebonyi State University, Abakaliki. Business Education graduates who are currently undergoing postgraduate programmes in Business Education were chosen for the study due to the fact that they could easily be contacted by the researcher. Statistical information from postgraduate school records of the institutions puts the figure of registered postgraduate Business Education students of two academic sessions (2009/2010 and 2010/2011) at 388. The data for this study were collected using a questionnaire developed and titled "Assessment of accounting competencies possessed by University Postgraduate Business Education Students to handle Entrepreneurship Business Challenges in Nigeria." It consisted of 41 items developed in line with the research question. The questionnaire comprised two parts - "A" and "B". Part A was for background information of the respondents and had 5 items while part B covered the research question and containing 36 items. The instrument was structured on a 4 point scale of Very Competent (VC) 4 points, Competent (C) -3 points, Fairly Competent (FC) -2 points, Not Competent (NC) -1 point. The face and content validity of the questionnaire was done by six experts: three from the Department of Vocational Education and one from the Department of Guidance and Counselling at the Nnamdi Azikiwe University, Awka plus two experts from the Department of Technical and Business Education, Delta State University, Abraka. These experts were selected based on the fact that they have knowledge and experience in test construction. The title, purpose of the study, research question and hypotheses were presented to them with a draft copy of the instrument and they were requested to thoroughly scrutinize the instrument for clarity and relevance of the items. To establish the internal consistency of the instrument, a questionnaire was administered to twenty-five (25) Business Education graduates who are currently undergoing their postgraduate programme in Business Education at the Olabisi Onabanjo University, Ago-Iwoye in Ogun State in south west Nigeria. The data collected were subjected to Cronbach alpha. A reliability coefficient of 0.94 was obtained. The researcher and eight research assistants trained by the researcher personally distributed the 388 copies of the questionnaire to the respondents. Some respondents completed their copies of the questionnaire and returned to the researcher and research assistants on the spot. In cases where on-the-spot completion and retrieval was not possible, the researcher and research assistants visited the institutions at later times as agreed with the concerned respondents to collect the completed copies of the questionnaire. The rate of return stood at 336, out of 388 (86.6\%).

The arithmetic mean and standard deviations were used to analyse the data on the research question. The z-test statistical tool was used for testing the hypotheses at 0.05 level of significance. Any item with a mean value between 
2.5 and above was regarded as competent by the respondents while any item whose mean rating was less than 2.5 was regarded as not competent by the respondents. A null hypothesis was rejected if the calculated value of the z-test (z-cal) was greater than the table value (t-tab). On the other hand, if the calculated value (z-cal) was less than the table value (t-tab), the null hypothesis was retained.

\section{Results}

\subsection{Research Question}

To what extent do Business Education graduates possess relevant competencies in accounting?

To answer research question 1, the mean and standard deviations were calculated from the frequency distribution. The result of the computation is shown in table 1 below.

Table 1: Mean Rating and Standard Deviation of the Respondents on Their Possessed Competencies in Accounting

\begin{tabular}{|c|c|c|c|c|}
\hline $\mathbf{S} / \mathbf{N}$ & Aspects of Accounting competencies & Mean & SD & Remarks \\
\hline 1 & Ability to keep and control stocks & 2.85 & 0.96 & Competent \\
\hline 2 & Ability to avoid unplanned expenditure & 2.75 & 0.83 & Competent \\
\hline 3 & Ability to develop skills of keeping accounting records of small-scale business & 2.80 & 0.80 & Competent \\
\hline 4 & Ability to determine profit of a particular period & 2.81 & 0.78 & Competent \\
\hline 5 & Ability to find out sources of capital to start business & 2.82 & 0.79 & Competent \\
\hline 6 & Ability to apply integrating business skills & 2.70 & 0.84 & Competent \\
\hline 7 & Ability to understand ways of recording business transactions & 2.85 & 0.88 & Competent \\
\hline 8 & Ability to keep accurate financial records & 2.95 & 0.80 & Competent \\
\hline 9 & Ability to be acquainted with new trends as regards accounting role in the business world. & 2.74 & 0.86 & Competent \\
\hline 10 & Ability to determine where and when to invest & 2.75 & 0.74 & Competent \\
\hline 11 & Ability to be acquainted with new trends in relation to accounting concepts and convention & 2.64 & 0.86 & Competent \\
\hline 12 & Ability to undertake simple audit and manage it properly. & 2.62 & 0.78 & Competent \\
\hline 13 & Ability to detect fraudulent practices & 2.72 & 0.82 & Competent \\
\hline 14 & Ability to handle various books of accounts & 2.70 & 0.76 & Competent \\
\hline 15 & Knowledge of Federal Government Tax laws & 2.59 & 0.76 & Competent \\
\hline 16 & Ability to prepare sales, cash and production budget & 2.69 & 0.86 & Competent \\
\hline 17 & Ability to interpret simple financial statements & 2.83 & 0.79 & Competent \\
\hline 18 & Knowledge of simple business law & 2.76 & 0.86 & Competent \\
\hline 19 & Knowledge of banking & 2.82 & 0.81 & Competent \\
\hline 20 & Knowledge of imprest system and its importance & 2.76 & 0.81 & Competent \\
\hline 21 & Ability to manage stock to avoid "stock outs” & 2.66 & 0.84 & Competent \\
\hline 22 & Ability to control stock to avoid overstocks & 2.70 & 0.88 & Competent \\
\hline 23 & Ability to avoid unbudgeted expenditure & 2.69 & 0.83 & Competent \\
\hline 24 & Preparation of tax codes & 2.45 & 0.91 & Not Competent \\
\hline 25 & Selecting settings of a department & 2.52 & 0.74 & Competent \\
\hline 26 & Setting up of a currency & 2.49 & 0.80 & Not Competent \\
\hline 27 & Designing of nominal records & 2.91 & 0.98 & Competent \\
\hline 28 & Creating, amending and deleting nominal records & 2.65 & 0.79 & Competent \\
\hline 29 & Structure for coding customer and supply records & 2.80 & 0.84 & Competent \\
\hline 30 & Preparation of VAT returns & 2.79 & 0.73 & Competent \\
\hline 31 & Invoicing and preparation of credit notes & 2.90 & 0.70 & Competent \\
\hline 32 & Ability to prepare product categories, and make product transfers & 2.47 & 0.80 & Not competent \\
\hline 33 & Sales \& purchases order processing & 2.95 & 0.90 & Competent \\
\hline 34 & Ability to perform year end routine & 2.87 & 0.79 & Competent \\
\hline 35 & Correction of errors made while posting transactions & 2.60 & 0.81 & Competent \\
\hline \multirow[t]{2}{*}{36} & Preparation of accounting routines/adjustments & 2.72 & 0.93 & Competent \\
\hline & Grand Mean/S.D = & 2.74 & 0.83 & Competent \\
\hline
\end{tabular}


The table contains thirty-six (36) accounting competencies. The mean scores of responses of the respondents show that they are competent in thirty-three (33). Ability to keep accurate financial records has the highest mean score of 2.95 and preparation of tax codes has the lowest mean score of 2.45. The grand mean of 2.74 and standard deviation of 0.83 confirm that the respondents are competent have the competences in accounting to handle entrepreneurship business challenges in Nigeria.

\section{Hypothesis 1}

There is no significant difference between male and female university Business Education graduates in the mean ratings of their possessed competencies in accounting.

Table 2: Z-test Result of The Difference on Respondents' Mean Rating of Their Possessed Accounting Competencies Based on Gender

\begin{tabular}{llllllll}
\hline Variables & $\mathbf{N}$ & Mean & SD & Df & z-cal & z-tab & Remarks \\
\hline Male & 176 & 62.55 & 15.29 & & & & \\
& & & & 334 & 0.978 & 1.96 & NS \\
Female & 160 & 60.34 & 25.91 & & & & \\
\hline
\end{tabular}

As can be seen from the table, the z-calculated value of 0.978 is less than z-tabulated value of 1.960 at 334 degree of freedom and 0.05 level of significance. Since the z-calculated value is less than the critical z-value, the null hypothesis is accepted.

\section{Hypothesis 2}

There is no significant difference between south east and south west universities Business Education graduates in the mean rating of their possessed competencies in accounting.

Table 3: Z-test Result of The Difference on Respondents' Mean Ratings of Their Possessed Accounting Competencies Based on Location

\begin{tabular}{llllllll}
\hline Variables & N & Mean & SD & Df & z-cal & z-tab & Remarks \\
\hline South East & 204 & 56.60 & 11.72 & & & & \\
& & & & 334 & 2.733 & 1.960 & Sig \\
South South & 132 & 54.88 & 10.16 & & & & \\
\hline
\end{tabular}

As can be seen from the table, the z-calculated value of 2.733 is greater than z-tabulated value of 1.960 at 334 degree of freedom and 0.05 level of significance. Since the z-calculated value is greater than the critical $z$-value, the null hypothesis is rejected.

\section{Hypothesis 3}

There is no significant difference between B.Sc. and M.Ed university Business Education graduates in the mean ratings of their possessed competencies in accounting.

Table 4: Z-test Result of The Difference on Respondents' Mean Ratings of Their Possessed Accounting Competencies Based on Qualification

\begin{tabular}{llllllll}
\hline Variables & $\mathbf{N}$ & Mean & SD & Df & z-cal & z-tab & Remarks \\
\hline B.Sc. & 283 & 80.47 & 15.20 & & & & \\
& & & & 334 & 1.08 & 1.960 & NS \\
M.Ed & 53 & 78.55 & 14.83 & & & & \\
\hline
\end{tabular}

As can be seen from the table, the z-calculated value of 1.08 is less than z-tabulated value of 1.960 at 334 degree of freedom and 0.05 level of significance. Since the z-calculated value is less than the critical z-value, the null hypothesis is accepted. 


\section{Hypothesis 4}

There is no significant difference between federal and state universities Business Education graduates in the mean ratings of their possessed competencies in accounting.

Table 5: Z-test Result of The Difference on Respondents' Mean Ratings of Their Possessed Accounting Competencies Based on University Type

\begin{tabular}{llllllll}
\hline Variables & $\mathbf{N}$ & Mean & SD & Df & z-cal & z-tab & Remarks \\
\hline Federal & 321 & 75.30 & 14.53 & & & & \\
& & & & 334 & 0.963 & 1.960 & NS \\
State & 15 & 73.81 & 12.82 & & & & \\
\hline
\end{tabular}

As can be seen from the table, the z-calculated value of 0.963 is less than z-tabulated value of 1.960 at 334 degree of freedom and 0.05 level of significance. Since the $\mathrm{z}$-calculated value is less than the critical z-value, the null hypothesis is accepted.

\section{Hypothesis 5}

There is no significant difference between full-time and part-time university Business Education graduates in the mean ratings of their possessed competencies in accounting.

Table 6: Z-test Result of The Difference on Respondents' Mean Ratings of Their Possessed Accounting Based on Mode of Study

\begin{tabular}{llllllll}
\hline Variables & $\mathbf{N}$ & Mean & SD & Df & z-cal & z-tab & Remarks \\
\hline Full-time & 300 & 68.16 & 13.32 & & & & \\
& & & & 334 & 1.13 & 1.960 & NS \\
Part-time & 36 & 66.45 & 12.40 & & & & \\
\hline
\end{tabular}

As can be seen from the table, the z-calculated value of 1.13 is less than z-tabulated value of 1.960 at 334 degree of freedom and 0.05 level of significance. Since the z-calculated value is less than the critical z-value, the null hypothesis is accepted.

\section{Discussion}

Findings of the study also reveal that university Business Education graduates are competent in accounting relative to entrepreneurial challenges. Ability to keep accurate financial records was recorded highest, followed by ability to keep and control stock, as well as to understand ways of recording business transactions. University Business Education graduates, from the findings, are able to interpret simple financial statements including knowledge of banking, sources of funds to start business. They are able to determine profit of a period and develop skills of keeping accounting records of small scale business. They have knowledge of imprest system and its importance as well as knowledge of simple business law. They are able to determine where and when to invest have ability to avoid unplanned expenditure. They have the knowledge that acquaints them with new trends of accounting records and handling of various books of account. They are also able to detect fraud. In agreement with this, Okpan (2006) identifies some accountings skills required by university Business Education graduates such as ability to keep accurate financial records, ability to understand ways of recording business transactions, ability to be acquainted with new trends as regards accounting role in the business world, ability to handle the various books of account and ability to interpret financial reports. Okpan (2006) also identifies these accounting skills: ability to apply integrating business skills, ability to control stock to avoid overstocks, ability to avoid unbudgeted expenditure and ability to prepare sales, cash and production budget. He further states that university Business Education graduates are able to manage stock to avoid 'stock outs'. They are acquainted with new trends in relation to accounting concepts and convention. They are able to undertake simple audit and manage it properly and they have knowledge of federal government tax laws. This study is consistent with Ekwue and Udoye's (2008) earlier study that identified accounting competencies required by university Business Education graduates - ability to keep and control stocks, ability to avoid unplanned expenditure, ability to determine profit of a particular period, ability to find out sources of capital to start business and ability to improve as well as develop basic 
skills in arithmetic. They further identified ability to understand ways of recording business transactions, ability to keep accurate financial records, ability to be acquainted with new trends as regards accounting role in the business world, ability to determine where and when to invest, ability to be acquainted with new trends in relation to accounting concepts and convention, ability to undertake simple audit and detect fraud. This study is also consistent with Azih (2010) who earlier identified the following accounting competencies: preparation of tax codes, selecting settings of a department, setting up of a currency, designing of nominal records , preparation of control accounts, creating, amending and deleting nominal records, creating of bank, cash and credit accounts, preparation of profit and loss account, structure for coding customer and supply records, handling of opening balances, preparation of check data, backups, compress data files, rebuild data files, month end financial reports and budget report, correction of errors made while posting transactions, preparation of a bank reconciliation statement, preparation of VAT returns, ability to perform year end routine, preparation of accounting routine/adjustments on a regular basis like recurring entries, fixed assets, prepayments accruals, writing off of bad debts and contra entries.

\section{Conclusion}

Based on the findings of the study, it is concluded that, relatively, the university Business Education graduates used for the study have the required accounting competencies to handle entrepreneurship challenges in Nigeria. However, they need to be trained and retrained in those areas of accounting competencies which they are not competent since the domain of accounting, when compared to economics and other related areas are far behind. With the information technology revolution, it requires integration with computers and communication technology. The in-depth knowledge of financial services is becoming very important for the accounting professionals. The accounting specialists for the international market must gear themselves to an in-depth knowledge of international trade, international finance and e-commerce, so as to serve the accounting professional more effectively.

\section{Recommendations}

Based on the findings of the study, the following recommendations are made:

1. Business Education graduates should undergo training in conferences and workshops to give them adequate knowledge on accounting concepts and principles.

2. Business Education students should take more courses in accounting to make them more competent in accounting concepts and principles.

3. Business Education department should be equipped by university authorities with adequate accounting textbooks.

\section{References}

Abdulkadir, A.A. (2011). The role of entrepreneurship education in empowering Nigerian youths. Business Education Journal, 8(1), 14-22.

Achilike, A.N., \& Okwuanaso, S.I. (2001). Competencies expected of national diploma accounting graduates of polytechnics as perceived by employers of labour. Journal of business and office education, 2(2), 66-73.

Adeosun, O.A. (2004). Competencies required of NCE accounting education graduates versus the N.C.C.E accounting education syllabus. Association of Business Educators of Nigeria. Book of Readings, 1(4), 185-197.

Adetifa, O., Ajileye, C., \& Oluwasanmi, R.O. (2001). Get Your Financial Accounting Right Book 1. Ibadan: Temia Press International.

Akume, R. C. (2006). Toward enhancing the managerial competence of NCE business education graduate entrepreneurs. Business education Journal, 5(2), 82-87.

Azih, N. (2010). Modern accounting skills required by accounting education students. Business Education Journal, $7(2), 120-130$.

Azih, N. (2013). Electronic accounting: An imperative tool for quality assurance in accounting education programme in the digital era. Nigeria Journal of Business Education, 1(2), 90-98.

Ehiametalor, E.T. (1990). Business and economics education. Principles and Methods. Evan Brothers (Nigeria publishers) Ltd. 
Ekwue, E.C., \& Udoye, R.N. (2008). Rating of accounting skills, needed for management of small business by entrepreneur. Business Education Journal, 4(3), 52-58.

Enete, F., Amusa, R.O., \& Eze, B. (2009). Competencies expected of Agricultural education students. Nigerian Vocational Journal, 12(1), 146-150.

Esene, R.A. (2012). Methods of teaching vocational business subjects. Agbor: Royal Pace Publications.

Federal Government of Nigeria (2009). National policy on education. Lagos: Federal Government Press.

Frank W. (2000). Business Accounting. U.K: Longman group publishers.

Hynes, B. (1996). Entrepreneurship education and graining: introducing entrepreneurship into non-business disciplines. Journal of European Industrial Training, 8(2), 22-29.

Nworgu, B.G. (1991). Educational research, basic issues and methodology. Owerri: Wisdom Publishers Ltd.

Okoli, B.E. (2013). Ensuring quality in the teaching of accounting in secondary schools. Nigerian Journal of Business Education, 1(2), 99-105.

Okoro, J. (2010). Assessment of office education skills required for entrepreneurial ventures. Business Education Journal, 7(2), 188-199.

Okpan, M.O. (2006). Business education competencies required for entrepreneurship development. Business Education Journal, 5(2), 24-32.

Okwuanaso, S.I. (2004). Improving standards in business education in Nigeria. Business Education Journal, 4(2), 12-23.

Osuala (2004). Principles and methods of business and computer education. Nsukka: Godjikson publication.

Osuwa, A.A. (2002). Information technology and its implications. Accounting Education Journal, 3(5), 52-58.

Ugeh, C.H. (2013). Emerging dimensions in accounting education and research. Association of Business Educators of Nigeria, Book of Reading, 3(1), 9-12. 